\title{
Az Európai Bíróság gyakorlatából
}

\section{Azonos nemü szülőkkel rendelkező uniós polgár gyermek szabad mozgáshoz való jogából a gyermek állampolgársága szerinti, az azonos nemü személyek szülöi jogállásának lehetöségét el nem ismerö tagállamra háruló kötelezettségek}

\section{LEHÓCZKI BALÁZS ${ }^{1}$}

Az Európai Unió (Unió) polgárainak és családtagjaiknak a tagállamok területén történö szabad mozgáshoz és tartózkodáshoz való jogáról szóló 2004/38/EK irányelv arra kötelezi a tagállamokat, hogy a jogszabályaikkal összhangban az állampolgáraik részére az állampolgárságot feltüntető személyazonositó igazolványt vagy útlevelet állitsanak ki annak érdekében, hogy azok gyakorolni tudják az Unió területén való szabad mozgáshoz és tartózkodáshoz való jogukat.

Ezzel kapcsolatban a Bulgáriából érkezett C-490/20. sz. Stolichna obshtina, rayon „Pancharevo” ügyben a Bíróságnak alkalma volt pontosítani az irányelv alapján az azonos nemü szülökkel rendelkezö uniós polgár gyermek szabad mozgáshoz való jogából a gyermek állampolgársága szerinti, az azonos nemü személyek szülői jogállásának lehetőségét el nem ismerö tagállamra háruló kötelezettségeket.

2021. december 14-én meghozott itéletében a Bíróság egyrészről megállapitotta, hogy az olyan uniós polgár kiskorú gyermek esetében, akinek a fogadó tagállam illetékes hatóságai által kiállitott születési anyakönyvi kivonata a gyermek szüleiként két azonos nemü személyt tüntet fel, a gyermek állampolgársága szerinti tagállam köteles a gyermek számára személyazonositó igazolványt vagy útlevelet kiállitani, annak elözetes megkövetelése nélkül, hogy saját nemzeti hatóságai születési anyakönyvi kivonatot állitsanak ki. A Bíróság másrészröl kimondta, hogy a gyermek állampolgársága szerinti tagállam - bármely más tagállamhoz hasonlóan - köteles elismerni a fogadó tagállam által kiállitott azon dokumentumot, amely lehetôvé teszi az emlitett gyermek számára, hogy e két személy mindegyikével gyakorolja a tagállamok területén való szabad mozgáshoz és tartózkodáshoz való jogát.

Kulcsszavak: uniós polgárok szabad mozgása, azonos nemü szülőkkel rendelkező gyermek, a fogadó tagállam által kiállított születési anyakönyvi

1 Tisztviselő, Európai Unió Bírósága Sajtó- és Tájékoztatási Osztály; oktató, Nemzeti Közszolgálati Egyetem, e-mail: balazs.lehoczki@curia.europa.eu 
kivonat elismerése, a gyermek állampolgársága szerinti tagállam kötelessége személyazonosító igazolvány vagy útlevél kiállítására

\section{Obligations on Member States not Allowing Parenthood for Persons of the Same Sex Regarding the Right to Free Movement of an EU Citizen Child with Parents of the Same Sex}

Directive 2004/38/EC on the right of citizens of the Union and their family members to move and reside freely within the territory of the Member States requires Member States, acting in accordance with their laws, to issue to their own nationals an identity card or passport stating their nationality in order that these persons can exercise that right.

In this context, in Case C-490/20 Stolichna obshtina, rayon "Pancharevo", which had been referred to it by the Bulgarian Courts, the Court of Justice was given the opportunity to precise the obligations on Member States not allowing parenthood for persons of the same sex regarding the right to free movement of an EU citizen child with parents of the same sex.

By its judgment of 14 December 2021, the Court, on the one hand, ruled that, in the case of a child, being a minor, who is a Union citizen and whose birth certificate, issued by the competent authorities of the host Member State, designates as that child's parents two persons of the same sex, the Member State of which that child is a national is obliged to issue to that child an identity card or a passport without requiring a birth certificate to be drawn up beforehand by its national authorities. On the other hand, the Court set out that the Member State of which that child is a national is obliged to recognise, as is any other Member State, the document from the host Member State that permits that child to exercise, with each of those two persons, the child's right to move and reside freely within the territory of the Member States.

Keywords: free movement of EU citizens, child with parents of the same sex, recognition of birth certificate issued by the host Member State, obligation for the Member State of which that child is a national to issue an identity card or a passport 


\section{Bevezetés}

Jóllehet az uniós tagállamok szabadságot élveznek a tekintetben, hogy rendelkeznek-e, vagy sem az azonos nemü személyek házasságáról, illetve gyermekvállalásáról a belső jogrendszerükben, e tagállamoknak mindazonáltal tiszteletben kell tartaniuk az uniós polgárok szabad mozgáshoz és tartózkodáshoz való jogával összefüggésben őket terhelő kötelezettségeket. E jog tartalmának meghatározása szempontjából különös jelentősége van az Unió polgárainak és családtagjaiknak a tagállamok területén történő szabad mozgáshoz és tartózkodáshoz való jogáról szóló irányelvnek (az irányelv). ${ }^{2}$

Ezzel összefüggésben a C-673/16. sz. Coman-ügyben ${ }^{3}$ 2018. június 5-én meghozott ítéletében az Európai Bíróság (a Bíróság) kimondta, hogy az uniós polgárok és családtagjaik szabad mozgáshoz és tartózkodáshoz való jogáról szóló uniós jogi rendelkezések értelmében vett „házastárs” fogalma magában foglalja az azonos nemü házastársakat. E tekintetben a Bíróság hangsúlyozta, hogy mialatt a tagállamok hatáskörébe tartozik annak eldöntése, hogy engedélyezik-e, illetve elismerik-e, vagy sem az azonos nemủ személyek közötti házasságkötést, nem akadályozhatják valamely uniós polgár szabad tartózkodáshoz való jogát azzal, hogy nem uniós állam állampolgárságával rendelkező, azonos nemű házastársától megtagadják a területükön való tartózkodáshoz való származékos jogot.

Az irányelv arra is kötelezi a tagállamokat, hogy a jogszabályaikkal összhangban az állampolgáraik részére az állampolgárságot feltüntető személyazonosító igazolványt vagy útlevelet állítsanak ki annak érdekében, hogy azok gyakorolni tudják az Unió területén való szabad mozgáshoz és tartózkodáshoz való jogukat.

Ezzel kapcsolatban egy Bulgáriából érkezett előzetes döntéshozatali ügyben ${ }^{4}$ a Bíróságnak a közelmúltban alkalma volt pontosítani az irányelv alapján az azonos nemű szülőkkel rendelkező uniós polgár gyermek szabad mozgáshoz való jogából a gyermek állampolgársága szerinti, az azonos nemủ személyek szülői jogállásának lehetőségét el nem ismerő tagállamra háruló kötelezettségeket.

\section{A Stolichna obshtina, rayon „Pancharevo” ügy tényállása}

V. M. A. - aki bolgár állampolgársággal rendelkezik - és K. D. K. 2015 óta Spanyolországban élnek, és 2018-ban kötöttek házasságot. Gyermekük, S. D. K. A. 2019-ben született Spanyolországban. E gyermek spanyol hatóságok által kiállított születési anyakönyvi kivonata a két anyát tünteti fel a gyermek szüleiként.

2 Az Európai Parlament és a Tanács 2004/38/EK irányelve (2004. április 29.) az Unió polgárainak és családtagjaiknak a tagállamok területén történő szabad mozgáshoz és tartózkodáshoz való jogáról, valamint az 1612/68/EGK rendelet módosításáról, továbbá a 64/221/EGK, a 68/360/ EGK, a 72/194/EGK, a 73/148/EGK, a 75/34/EGK, a 75/35/EGK, a 90/364/EGK, a 90/365/EGK és a 93/96/EGK irányelv hatályon kívül helyezéséről.

3 A C-673/16. sz. Coman-ügyben 2018. június 5-én hozott ítélet.

4 A C-490/20. sz. Stolichna obshtina, rayon „Pancharevo” ügyben 2021. december 14-én hozott ítélet. 
Mivel a bolgár személyazonosító igazolvány megszerzéséhez a bolgár hatóságok által kiállított születési anyakönyvi kivonatra volt szükség, V. M. A. azzal a kérelemmel fordult a szófiai önkormányzathoz, hogy állítsa ki azt S. D. K. A. számára. V. M. A. - kérelmének alátámasztása céljából - csatolta S. D. K. A. születési anyakönyve spanyol anyakönyvi nyilvántartásból származó kivonatának bolgár nyelvű hiteles fordítását.

A szófiai önkormányzat felszólította V. M. A.-t, hogy igazolja S. D. K. A. származását a biológiai anyjának személyazonosságát illetően. A Bulgáriában hatályos születési anyakönyvi kivonatminta ugyanis csak egy rovatot tart fenn az „anya” számára, és egy másikat az „apa” számára, ezekben a rovatokban pedig csak egyetlen név szerepelhet. Egyébiránt a bolgár családjogi törvénykönyv értelmében az anyai ágon való leszármazást a születés határozza meg, a gyermek anyja pedig - asszisztált reprodukciós eljárások esetében is - az őt megszülő nő.

Miután V. M. A. úgy ítélte meg, hogy nem köteles a kért tájékoztatást megadni és ezért nem tett eleget az említett felszólításnak, a szófiai önkormányzat megtagadta a kért születési anyakönyvi kivonat kiállítását az érintett gyermek biológiai anyjának személyazonosságára vonatkozó információk hiánya, valamint amiatt, hogy két nőnemủ szülőnek a születési anyakönyvi kivonatban való feltüntetése az azonos nemúek házasságát nem engedélyező Bulgária közrendjébe ütközik.

V. M. A. keresetet nyújtott be e határozattal szemben a szófiai közigazgatási bírósághoz, amely előzetes döntéshozatal iránti kérelmet terjesztett a Bíróság elé. Ennek keretében a bolgár bíróság arra a kérdésre kívánt választ kapni, hogy a valamely bolgár állampolgár más tagállamban bekövetkezett, és ezen utóbbi tagállam által két anyát feltüntető születési anyakönyvi kivonattal igazolt születése bejegyzésének a bolgár hatóságok általi megtagadása sérti-e az uniós jog ${ }^{5}$ által az említett állampolgárra ruházott jogokat. Az érintett gyermek születése bejegyzésének a megtagadása ugyanis megnehezítheti a bolgár személyazonosító igazolvány kiállítását, és ennélfogva akadályozhatja e gyermek számára a szabad mozgáshoz való jog gyakorlását, és így az őt uniós polgárként megillető jogok teljes körủ gyakorlását.

A bolgár bíróság tehát lényegében azt kívánta megtudni, hogy az uniós jog kötelezi-e Bulgáriát születési anyakönyvi kivonat kiállítására - személyazonosító igazolvány megszerzése céljából - egy bolgár állampolgársággal rendelkező olyan gyermek számára, akinek egy másik tagállamban való megszületését az e másik tagállam hatóságai által kiállított olyan születési anyakönyvi kivonat igazolja e tagállam nemzeti jogának megfelelően, amely e gyermek anyjaiként egy bolgár állampolgárt és annak házastársát tünteti fel, de nem határozza meg, hogy e két nő közül melyik szülte az említett gyermeket.

5 Az EUMSZ 20. és EUMSZ 21. cikke, valamint az Európai Unió Alapjogi Chartájának a 7., 24. és 45. cikke. 


\section{A Stolichna obshtina, rayon „Pancharevo” ügyben hozott ítélet}

2021. december 14-én meghozott ítéletében ${ }^{6}$ a Bíróság megállapította, hogy az olyan uniós polgár kiskorú gyermek esetében, akinek a fogadó tagállam illetékes hatóságai által kiállított születési anyakönyvi kivonata a gyermek szüleiként két azonos nemü személyt tüntet fel, a gyermek állampolgársága szerinti tagállam köteles egyrészről a gyermek számára személyazonosító igazolványt vagy útlevelet kiállítani, annak előzetes megkövetelése nélkül, hogy saját nemzeti hatóságai születési anyakönyvi kivonatot állítsanak ki, valamint másrészről - bármely más tagállamhoz hasonlóan - köteles elismerni a fogadó tagállam által kiállított azon dokumentumot, amely lehetővé teszi az említett gyermek számára, hogy e két személy mindegyikével gyakorolja a tagállamok területén való szabad mozgáshoz és tartózkodáshoz való jogát.

E következtetés levonásához a Bíróság először is emlékeztetett arra, hogy azzal a céllal, hogy a tagállamok állampolgárai gyakorolhassák a tagállamok területén való szabad mozgás és tartózkodás jogát - amelyet az EUMSZ 21. cikk (1) bekezdése minden uniós polgár számára elismer -, az irányelv arra kötelezi a tagállamokat, hogy jogszabályaikkal összhangban állampolgáraik részére az állampolgárságot feltüntető személyazonosító igazolványt vagy útlevelet állítsanak ki.

Ennélfogva, mivel S. D. K. A. bolgár állampolgár, a bolgár hatóságok - új születési anyakönyvi kivonat kiállításától függetlenül - kötelesek számára a spanyol hatóságok által kiállított születési anyakönyvi kivonatban szereplő vezetéknevét feltüntető személyazonosító igazolványt vagy útlevelet kiállítani.

Az ilyen dokumentumnak - akár önmagában, akár a fogadó tagállam által kiállított más dokumentummal együtt - lehetővé kell tennie az S. D. K. A.-hoz hasonló gyermek számára, hogy gyakorolja a szabad mozgáshoz való jogát mindkét anyjával, akiknek az e gyermek szüleiként fennálló jogállását a fogadó tagállam az irányelvnek megfelelő tartózkodás során megállapította.

A tagállamok állampolgárai számára az EUMSZ 21. cikk (1) bekezdése által elismert jogok közé tartozik ugyanis a szokásos családi élet fenntartása mind a fogadó tagállamban, mind visszatéréskor abban a tagállamban, amelynek állampolgárai, olyan módon, hogy családtagjaik is mellettük lehessenek. Mivel a spanyol hatóságok jogszerủen állapították meg, hogy biológiai vagy jogi leszármazáson alapuló rokoni kapcsolat áll fenn S. D. K. A. és két szülője között, ezt pedig az ezen utóbbiak gyermeke számára kiállított születési anyakönyvi kivonatban igazolták, ennélfogva V. M. A. és K. D. K. esetében - az EUMSZ 21. cikk és az irányelv alapján - olyan kiskorú uniós polgár szüleiként, aki felett tényleges szülői felügyeletet gyakorolnak, valamennyi tagállamban el kell ismerni a gyermek elkíséréséhez való jogot e jog gyakorlása során.

Ebből egyrészről az következik, hogy a tagállamok kötelesek elismerni ezt a leszármazáson alapuló rokoni kapcsolatot annak érdekében, hogy lehetővé tegyék S. D. K. A. számára, hogy mindkét szülőjével gyakorolja a szabad mozgáshoz való jo-

6 Az ítélet feldolgozása a Bíróság 221/2021. sz. sajtóközleménye alapján történt. 
gát. Másrészről a két szülőnek olyan dokumentummal kell tudnia rendelkezni, amely feljogosítja őket az e gyermekkel való utazásra. A fogadó tagállam hatóságai a legalkalmasabbak arra, hogy ilyen dokumentumot állítsanak ki, amely öltheti születési anyakönyvi kivonat formáját, és amelyet a többi tagállam köteles elismerni.

Mindezzel összefüggésben a Bíróság hangsúlyozta, hogy a személyi állapot kétségtelenül a tagállamok hatáskörébe tartozó terület, és hogy a tagállamok szabadságot élveznek a tekintetben, hogy az azonos nemű személyek házasságát vagy szülői jogállásukat a nemzeti jogukban előírják-e, vagy sem. E hatáskör gyakorlása során azonban minden tagállamnak tiszteletben kell tartania az uniós jogot, és különösen a Szerződésnek az uniós polgárok szabad mozgásával és tartózkodásával kapcsolatos rendelkezéseit, e célból pedig minden tagállamnak el kell ismernie a személyeknek a valamely más tagállamban - az e tagállam jogának megfelelően - megállapított személyi állapotát.

Márpedig a Bíróság szerint a jelen ügyben nem sérti az érintett tagállam nemzeti identitását, és nem is fenyegeti e tagállam közrendjét a tagállam azon kötelezettsége, hogy egyrészt személyazonosító igazolványt állítson ki olyan gyermek számára, aki e tagállam állampolgára, de másik tagállamban született, és aki számára ebben e másik tagállamban olyan születési anyakönyvi kivonatot állítottak ki, amely két azonos nemű személyt tüntet fel a gyermek szüleiként, másrészt pedig az a kötelezettsége, hogy elismerje az e gyermek és e két személy mindegyike közötti leszármazáson alapuló rokoni kapcsolatot a gyermek jogainak az EUMSZ 21. cikk és az ezzel kapcsolatos másodlagos jogi aktusok alapján, általa történő gyakorlása során. Az ilyen kötelezettség ugyanis nem jelenti azt, hogy az érintett tagállamnak a nemzeti jogában elő kell írnia az azonos nemű személyek szülői jogállását, vagy hogy - az e gyermek uniós jogból eredő jogainak gyakorlásától eltérő célokból - el kell ismernie az említett gyermek és a fogadó tagállam hatóságai által kiállított születési anyakönyvi kivonatban a gyermek szüleiként feltüntetett személyek közötti leszármazáson alapuló rokoni kapcsolatot.

Végül az a nemzeti intézkedés, amely akadályozhatja a személyek szabad mozgásának gyakorlását kizárólag akkor igazolható, ha ezen intézkedés összhangban van az Európai Unió Alapjogi Chartájában (a Charta) biztosított alapvető jogokkal. ${ }^{7}$ Ellentétes azonban a Charta 7. és 24. cikkében biztosított alapvető jogokkal, ha a szabad mozgáshoz való jogának gyakorlása keretében megfosztják a gyermeket a valamelyik szülőjével fennálló kapcsolatától, vagy ha számára e jog gyakorlását ténylegesen lehetetlenné vagy rendkívül nehézzé teszik amiatt, hogy szülei azonos neműek.

$7 \quad$ A jelen ügyben a Charta 7. cikkében biztosított, a magán- és családi élet tiszteletben tartásához való jog, valamint a gyermeknek a Charta 24. cikkében garantált jogai, különösen a gyermek mindenek fölött álló érdekének figyelembevételéhez való jog, valamint a két szülöjével rendszeres, személyes és közvetlen kapcsolat fenntartásához való jog a releváns. 


\section{Zárszó}

A Coman-ügyben 2018-ban meghozott ítélete után a Bíróság ismét olyan döntést hozott, amelyben az uniós polgárok szabad mozgáshoz és tartózkodáshoz való jogának és a személyi állapot meghatározására irányuló tagállami szabályozásnak az összeütközését kellett feloldania. Ezen összeütközés lényege abban áll, hogy a személyi állapot meghatározása, ideértve különösen az azonos nemủ személyek házasságáról és szülői jogállásáról való rendelkezést, lényegében a tagállamok kizárólagos hatáskörébe tartozik, ugyanakkor e hatáskör gyakorlása akadályozhatja vagy korlátozhatja az uniós polgárok szabad mozgáshoz és tartózkodáshoz való jogának az érvényesülését.

A Coman-ügyben hozott ítéletéhez hasonlóan a Bíróság a Stolichna obshtina, rayon „Pancharevo” ügyben hozott ítéletében is világossá tette, hogy a személyi állapot meghatározása a tagállamok hatáskörébe tartozó terület, és hogy a tagállamok szabadságot élveznek a tekintetben, hogy az azonos nemủ személyek házasságáról vagy szülői jogállásáról a nemzeti jogukban rendelkeznek-e, vagy sem. A Bíróság ugyanakkor a Coman-ítélet után ismételten hangsúlyozta, hogy e hatáskör gyakorlása során a tagállamoknak tiszteletben kell tartaniuk az uniós jogot, és különösen a Szerződésnek az uniós polgárok szabad mozgásával és tartózkodásával kapcsolatos rendelkezéseit.

Ez utóbbi kötelezettség pedig a szóban forgó mindkét ügyben az azonos nemủ személyek házasságáról vagy szülői jogállásáról nem rendelkező tagállamok azon járulékos kötelezettségének a megállapításához vezetett, hogy biztosítsák a valamely más tagállam joga szerint házastársi, illetve szülői jogállást szerzett ilyen személyek vagy azok gyermekei számára az uniós polgárok szabad mozgáshoz és tartózkodáshoz való jogának a gyakorlását. 